\title{
18 ay üstü çocuklarda gelişimsel kalça displazisi ve tedavisi
}

\section{Treatment of developmental dysplasia of the hip in children older than 18 months}

\author{
Ibrahim Sungur, Mahmut Ercan Çetinus
}

\section{S. B. Haseki Eğitim ve Araştırma Hastanesi, Ortopedi ve Travmatoloji Kliniği, İstanbul}

\begin{abstract}
Yürüme çağında tanı konulan hastalar hekime genellikle aileleri tarafından bacakta kısalık ve aksamanın fark edilmesi sonucu getirilirler. Geç başvurunun nedenlerinin ailenin sosyo-ekonomik açıdan ve eğitim bakımından yetersizliği yanında, daha önce gidilen aile hekimi ve pediatri hekimlerinin gelişimsel kalça displazisi (GKD)'nin önemi hakkında yetersiz bilgiye sahip olmaları olduğu da düşünülmektedir.
\end{abstract}

GKD'nin tedavisinde amaç, mümkün olan en kısa zamanda redüksiyonu sağlamak ve proksimal femur ve asetabulumun gelişimine uygun ortamı oluşturmaktır. GKD tanısı ne kadar geç konulursa, asetabular ve femoral remodelizasyon potansiyeli o kadar azalır ve tedavi o kadar karmaşık hale gelir; dejeneratif eklem hastalığı gelişme riski de artar.

On sekiz ay sonrasında, eklem kapsülü superiora doğru uzadığı için, genellikle anterior açık redüksiyon yapılır ve kapsül redüksiyon sonrasında uygun gerginlikte daraltılır. Asetabulum ve proksimal femurun remodelizasyon potansiyeli azalmaya başladığından, aynı seansta genellikle pelvik osteotomi de uygulanır. Rotasyonel pelvik osteotomilerin ve asetabuloplasti prosedürlerinin birbirlerine göre avantajları ve dezavantajları vardır. İki yaşından küçük çocuklarda açık redüksiyon sonrasında asetabular gelişmeyi radyografik olarak takip ederek asetabular osteotomiyi daha sonra yapmayı tercih eden cerrahlar da vardır. İki yaşından sonra, açık redüksiyon ve pelvik osteotomiye genellikle femoral kısaltma da eklenir. Burada amaç, femur başı üzerindeki temas basıncını azaltarak avasküler nekroz gelişme riskini azaltmaktır. Açık redüksiyon öncesi uzun süreli traksiyon yapılmasını tercih eden cerrahlar olmasına rağmen, günümüzde femoral kısaltmanın avasküler nekrozu önlemede daha etkin olduğunu ispatlayan çalışmalar vardır.

GKD tanı ve tedavisinde anahtar, erken tanıdır. Erken girişim, \%95 başarı oranı ve düşük komplikasyon riski ile sonuçlanır. illk tedavi eden hekimin sağlıklı bir kalça elde etme şansının en fazla olduğu unutulmamalıdır.

Anahtar sözcükler: kalça displazisi, gelişimsel; tanı; tedavi; osteotomi, pelvik; femoral
Patients at walking age are generally brought to the clinic because of the recognition of limping and limb length discrepancy by their families. Reasons for late presentation are thought to be inadequate knowledge of the primary care physicians and pediatricians on developmental dysplasia of the hip (DDH), as well as the poor socio-economical and educational level of the family.

The purpose of treatment in developmental dysplasia of the hip is to ensure reduction of the hip joint as soon as possible, in order to provide an adequate environment for development of acetabulum and the proximal femur. The later the diagnosis is made, the less the acetabular and proximal femoral remodeling potential remains and the more complicated the required treatment becomes; besides, the risk of development of degenerative joint disease increases.

Because joint capsule is elongated superiorly after 18 months, the preferred method of open reduction is generally anterior open reduction with adequate capsulorrhaphy. Pelvic osteotomy is generally added to open reduction considering the relatively less potential remained for acetabular remodelling. Rotational pelvic osteotomies and acetabuloplasty procedures have advantages and disadvantages compared to each other. In children younger than two years old, some surgeons prefer to follow acetabular development after open reduction by radiography and reserve the pelvic osteotomy for later. After two years, generally femoral shortening is added to open reduction and concomitant pelvic osteotomy. The purpose of femoral shortening is to decrease the contact pressure on the femoral head and thus reduce the risk of avascular necrosis. Although some surgeons prefer long period of traction before open reduction, femoral shortening is proven to be more effective for the prevention of avascular necrosis.

Early diagnosis is the key for diagnosis and treatment of DDH. Early management achieves $95 \%$ success rate and low complication risk. One should remember that the first treating surgeon has a higher chance of acquiring a healthy hip.

Key words: hip dysplasia, developmental; diagnosis; treatment; osteotomy, pelvic; femoral

- Illetişim adresi: Op. Dr. İbrahim Sungur, S. B. Haseki Eğitim ve Araştırma Hastanesi Ortopedi ve Travmatoloji Kliniği, İstanbul Tel: 0532 - 4564077 e-posta: sungurhaseki@gmail.com

- Geliş tarihi: 3 Eylül 2014 Kabul tarihi: 3 Eylül 2014 
alça ultrasonografisinin rutin olarak kullanı$\mathrm{mI}$, her ne kadar gelişimsel kalça displazisinin erken tanısını ve tedavisini mümkün hale getirmişse de, ülkemizde yürümeye başladıktan sonra aksadığı fark edilerek ilk kez doktor muayenesine götürülen çocuk sayısı oldukça fazladır. Geç tanı konulduğunda, hem tedavi daha karmaşık bir hal alır hem de tedaviden beklenilen sonuçlar kötüleşir.

Kalça ekleminin normal bir şekilde büyüyüp gelişmesi için asetabular ve triradiat kıkırdakların dengeli bir şekilde büyümesi ve asetabulum içinde doğru şekilde yerleşmiş femur başının bulunması gereklidir. Proksimal femur ve asetabular kıkırdak kompleksinin gelişimi birbirine bağlıdır. ${ }^{[1]}$ Proksimal femurun üç büyüme plağı vardır: büyük trokanter büyüme plağı, fizyel büyüme plağı ve ikisini birleştiren femur boynu lateral büyüme plağı. Proksimal femurun normal gelişimi bu üç büyüme plağının dengeli büyümesine bağlıdır ve kasların çekmesinden, yük taşıma sırasında kalça eklemine aktarılan güçlerden, kas tonusundan, dolaşımdan ve eklem beslenmesinden etkilenir. Bu etmenlerdeki değişiklikler proksimal femur gelişimini önemli şekilde etkiler. Cerrahi girişime ya da inflamatuvar süreçlere bağlı hiperemi bu büyüme plaklarının büyümesini uyarabilir. ${ }^{[2]}$

Proksimal femur büyüme plağı femur uzunluğuna yaklaşık \%30, ekstremite uzunluğuna ise \%13 katkıda bulunur ve dolaşım bozukluğuna neden olacak bir hasar bu plağın büyümesini bozduğundan ve trokanterik ve lateral femur boynu plakları büyümeye devam edeceğinden, proksimal femurda varus deformitesine neden olur. Trokanter ve proksimal femur fizislerinin büyümesi arasındaki ilişki artiküler trokanterik mesafe ile ölçülür ve oranı sabit kalmalıdır. Artiküler trokanterik mesafe; büyük trokanterin tepe noktası ile femur başının superior artiküler yüzeyi arasındaki mesafedir. ${ }^{[2]}$

\section{GELIŞiMSEL KALÇA DISPLAZISINDE ASETABULAR GELIŞME}

Asetabulumun normal büyüme ve gelişmesi için birincil uyaran asetabulum içinde yerleşmiş olan femur başının varlığıdır. Tanıda ve tedavide gecikme olduğun$\mathrm{da}$, normal büyüme ve gelişme de gerçekleşemez. Eğer konsantrik redüksiyon sağlanır ve bu pozisyon korunursa, asetabulumun uzun yıllar boyunca iyileşme ve büyüme potansiyeli vardır. ${ }^{[3]}$

Displastik bir kalçanın redüksiyon sonrası normale dönebileceği yaş konusu tartışmalıdır. ${ }^{[4]}$ Asetabulum gelişiminin yeniden başlaması ve yeterliliği multifaktöryel bir sorundur ve redüksiyonun sağlanma yaşına ve asetabular kıkırdağın ve proksimal femurun büyüme potansiyelinin normal olup olmamasına bağlıdır. Asetabular kıkırdağın normal büyümeyi yakalama kapasitesi intrensek büyüme potansiyeline ve sublukse ya da lukse femur başı tarafından veya tekrarlayan redüksiyon girişimleri sırasında hasar görüp görmemesine bağlıdır. GKD hastalarında, özellikle de geç tanı konulmuş olgularda, aksesuvar ossifikasyon merkezleri asetabular gelişime katkıda bulunurlar. Asetabulumda aksesuvar kemikleşme merkezleri, normal kalçaların yalnız \%2'sinde ve 11 yaşından önce nadiren görülür. GKD nedeniyle tedavi edilen hastaların ise \%60'ında görülebilir ve redüksiyondan sonra 6 aydan 10 yıla kadar gelişebilir. ${ }^{[2]}$ Bu aksesuvar merkezler, asetabular kıkırdağın çeperinde oluşur ve displaziye bağlı birincil bir anormallik olabileceği gibi, daha büyük olasılıkla disloke ya da sublukse pozisyondaki femur başı ve boynunun oluşturduğu basınç hasarına ya da kapalı veya açık tedaviye bağı ikincil bir anormallik de olabilir. Tedavi edilen GKD hastalarında çekilen grafilerde, asetabular gelişimin devam edip etmediğini anlamak amacıyla bu ikincil ossifikasyon merkezlerinin varlığı araştırılmalıdır. Aksesuvar ossifikasyon merkezlerinin görülmesi, rezidüel asetabular displazi varlığında cerrahi girişime gerek olup olmadığına karar vermede önemli bir etmendir. Bu merkezlerin varlığı asetabular kıkırdakta gelişmenin devam ettiğini gösterir, ancak asetabulumun normal gelişeceğini garanti etmez. ${ }^{[5]}$

\section{GKD'DE GEÇ TANI}

Yürüme çağında tanı konulan hastalar genellikle aileleri tarafından yürümenin gecikmesi, bacakta kısalık ve aksamanın fark edilmesi sonucu getirilirler. Geç başvurunun nedenleri arasında ailenin sosyoekonomik ve eğitim bakımından yetersizliği yanında, daha önce gidilen aile hekimi ve pediatri hekimlerinin GKD'nin önemi hakkında yetersiz bilgiye sahip olmaları da sayılabilir. ${ }^{[6]}$

GKD'de erken tanı konulmadığında normal kalça büyüme ve gelişmesi bozulur ve ikincil adaptif değişiklikler gelişir. Geç tanı konulan GKD'de en güvenilir fizik muayene bulgusu abduksiyon kısıtlılığıdır. Abduksiyon kısıtlılığının nedeni kalça subluksasyonu ya da çıkığına bağlı gelişen adduktor longus kas spazmıdır.

Tek taraflı olgularda ilk göze çarpan klinik bulgu, anormal duruş ve topallamadır. Pelvik oblisite ve Trendelenburg bulgusu dikkati çeker. Atılan her adımın duruş evresinde pelvisin normalde yatay pozisyonda kalması gerekirken, çıkık kalçada, abduktor kaslardaki güçsüzlük nedeniyle karşı tarafta aşağıya doğru kaydığı görülür (Trendelenburg bulgusu) (Şekil 1).

Omurga disloke tarafa doğru bükülür ve tutulan tarafta vertikal teleskop hareketi gözlenir. Femoral arter nabzı karşı tarafa göre daha zayıf hissedilir. Her iki kalça ve $\operatorname{diz} 90^{\circ}$ fleksiyona alındığında, dizler arasında mesafe farkı olduğu görülür (Galeazzi-Allis bulgusu) (Şekil 2). 


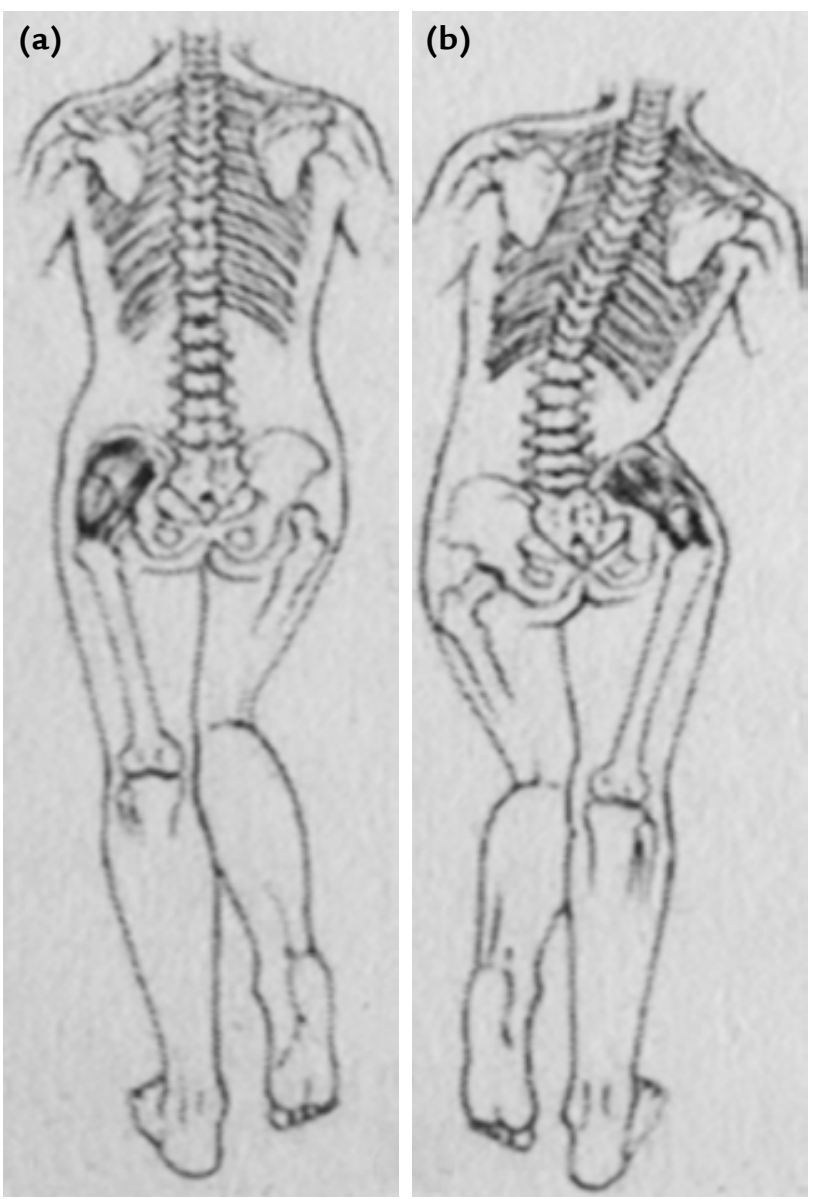

Şekil 1. a, b. Trendelenburg bulgusu.

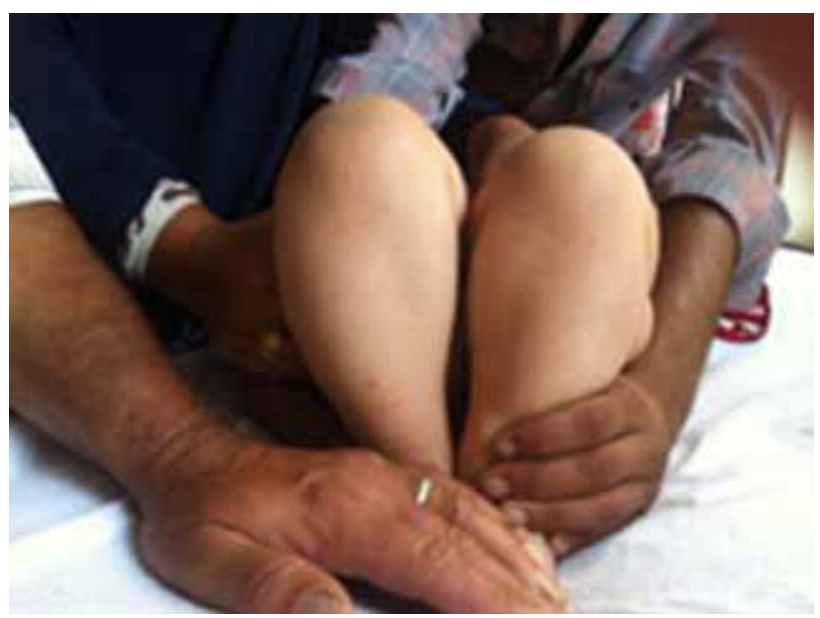

Şekil 2. Galeazzi bulgusu.

Bilateral çıkıklarda perineal bölge genişlemiş ve trokanter majorlar belirginleşmiştir. Pelvisin artmış öne inklinasyonu ve femur başının arkaya deplasmanı nedeniyle hiperlordoz vardır (Şekil 3). Ördekvari yürüyüş gözlenir.

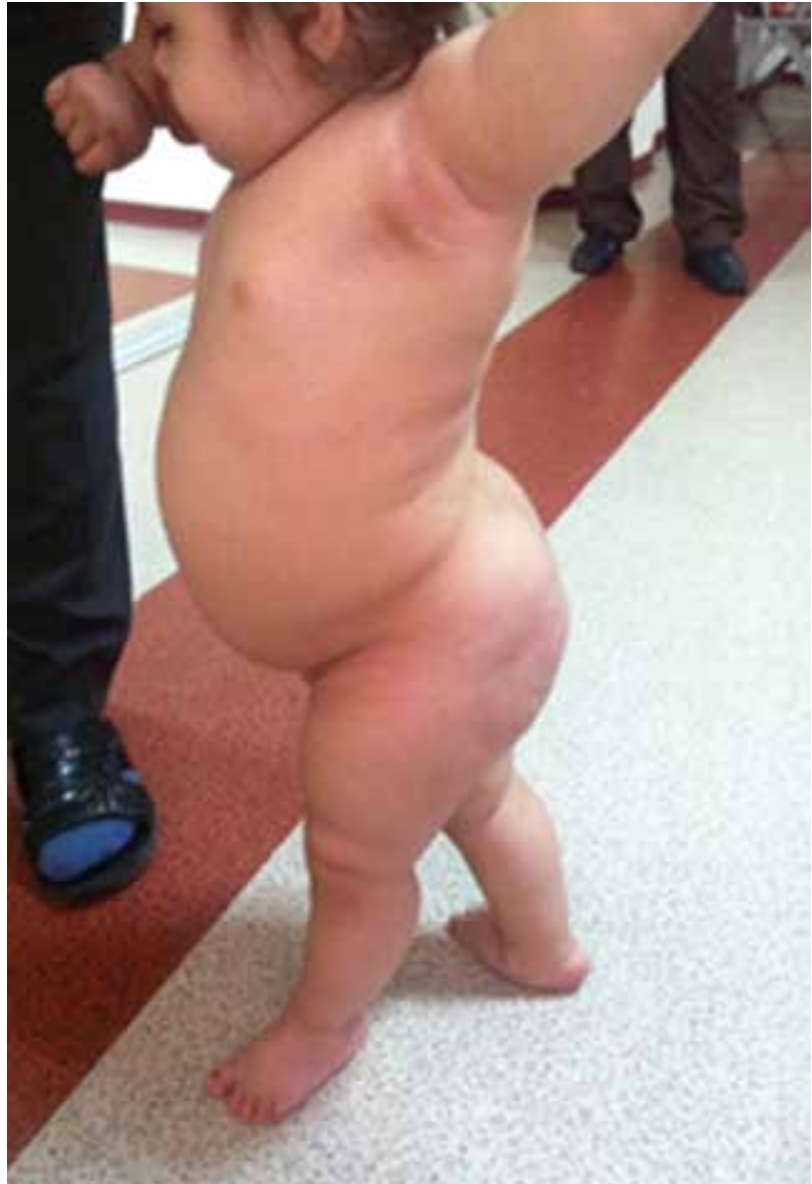

Şekil 3. Yirmi altı aylık bilateral GKD saptanan kız çocuğunda hiperlordoz dikkati çekmekte.

\section{RADYOGRAFi}

Geç başvuran bir GKD hastasına çekilen pelvis AP grafisinde görülecek klasik radyografi bulguları; asetabular indekste artış, Shenton hattında bozulma, gözyaşı figürünün görülememesi, femur başı kemikleşme merkezinin görülmesinin gecikmesi ya da sağlam tarafa göre daha küçük görülmesi, femur başı örtünmesinde azalma, Wiberg'in merkez-kenar (CE) açısında daralma ve Sharp aşısında küçülmedir (Şekil 4). ${ }^{[2]}$

Asetabular indeks; asetabulumun tabanı ile üst dış ossifıye kenarını birleştiren çizginin Hilgenreiner hattı ile arasında kalan açıdır. Asetabulumun normal inklinasyonunu gösterir ve yenidoğanda $30^{\circ}$ 'den küçük olmalıdır. İki yaşına kadar $20^{\circ}$ civarına inmesi gerekir. Sekiz yaşından küçük çocuklarda asetabular indeksin ölçümü, asetabular gelişimin ölçülmesi için uygun bir yöntemdir. ${ }^{[2]}$

Triradiat kıkırdak kapandıktan sonra Sharp'ın asetabular açısı (gözyaşı figürünün alt köşesinden asetabulumun üst köşesine çizilen çizgi ile Hilgenreiner 


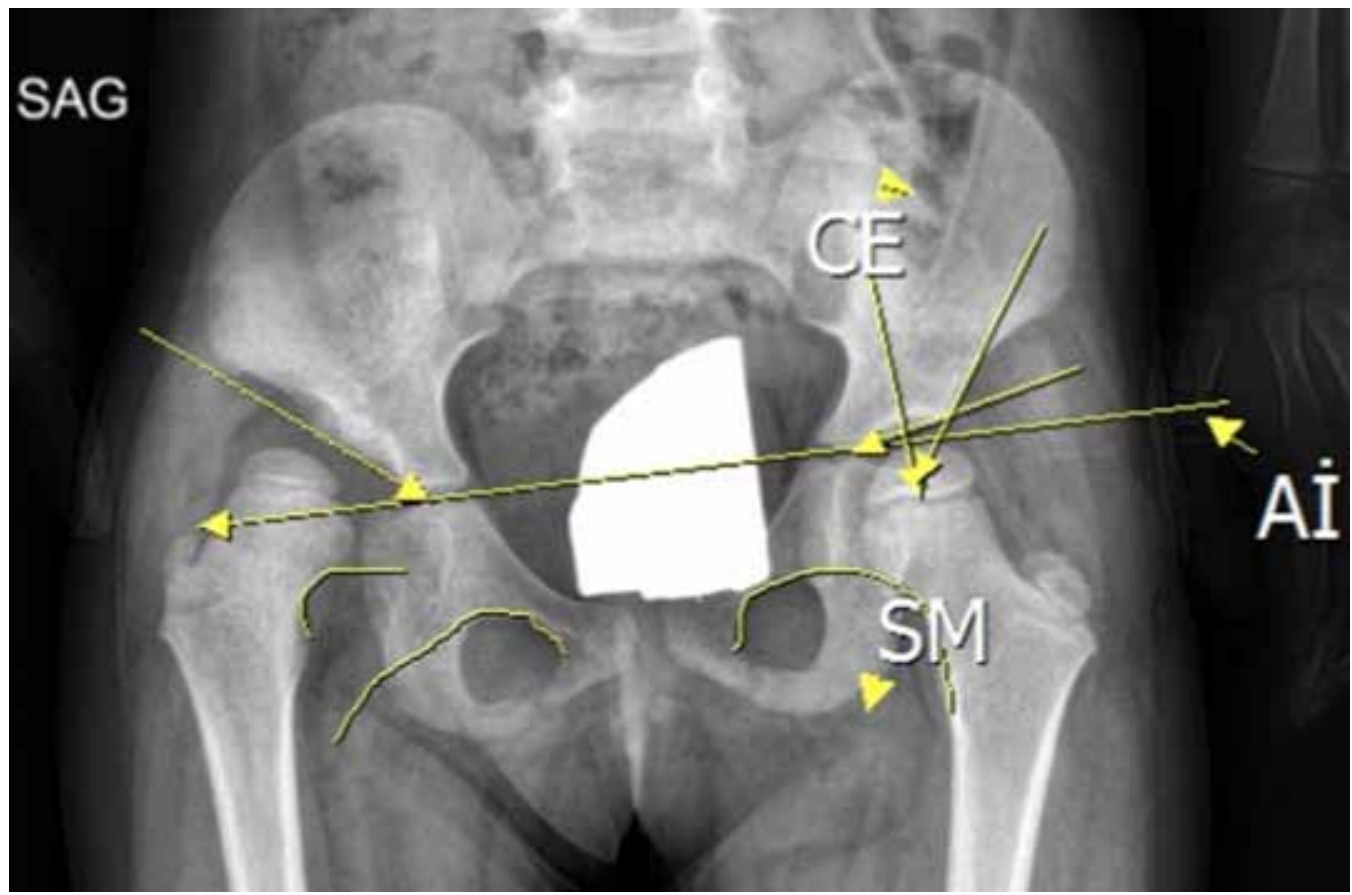

Şekil 4. Pelvis AP grafide: CE, center-edge = merkez-kenar açısı; AI, asetabular indeks; SM, ShentonMenard hattı görülüyor.

çizgisi arasındaki açı) asetabular displazinin ölçümünde yararlıdır.

CE açısı beş yaşından büyük çocuklarda ölçülebilir ve en çok erişkin hastalardaki asetabular displazi ölçümünde kullanılır. Wiberg tarafından 1933 yılında tanımlanan bu açı, femur başı merkezinden Hilgenreiner çizgisine çizilen çizgi ile yine femur başı merkezinden kemikleşmiş asetabulumun en dış noktasına çizilen çizgi arasındaki açıdır. Normal fizyolojik değeri $20-40^{\circ}$ arasıdır. $20^{\circ}$ 'nin altında olması displaziyi gösterir. ${ }^{[3]}$

Shenton hattı, femur başının inferiorundan obturator foramenin superior sınırı boyunca devamlılık gösteren bir yay şeklindedir ve asetabular displazinin niteliksel göstergesidir. Bütün kalça grafilerinde Shenton hattı devamlılık göstermelidir. Bu hatta bozulma, proksimal femur ve asetabulum arasındaki ilişkide bozulmayı işaret eder. ileride, kalçada dejenerasyonu önlemek için bu ilişki restore edilmelidir.

Adolesanlarda ve genç erişkinlerde, anterior asetabular yetmezliğin ölçümünde kalça yalancı profil görüntüsü kullanılabilir.

Femur boynu anteversiyon açısının ölçümü için en güvenilir yol transvers kesitlerin alındığı tomografik incelemedir.

Radyografiler asetabulum ve proksimal femurun yalnızca ossifiye olan kısımlarını gösterir. Femur başı henüz kemikleşmemiş asetabular kıkırdak tarafından mükemmel şekilde örtülüyor olabilir. Bu durumda nonossifiye kıkırdağın durumu artrografi ile değerlendirilebilir. Bu kıkırdak kemikleşmezse rezidüel displazi ve sonucunda da subluksasyon ve kalça ekleminde dejenerasyon gelişebilir. Artrografinin derin sedasyon ya da genel anestezi gerektiren invaziv bir girişim olması kullanımını sınırlar. Bu nedenle ancak redüksiyon sonrası redüksiyonun uygunluğunu ve stabilitesini değerlendirmek için kullanılır. ${ }^{[2]}$

Bilgisayarlı tomografi (BT), açık ya da kapalı redüksiyon sonrası pelvipedal alçı içinde kalçanın pozisyonunu değerlendirmek için kullanılabilir. Sadece asetabulumdan kesit alındığı için radyasyon dozu daha azdır; ayrıca, çocuk alçının içinde hareket edemeyeceğinden anesteziye de gerek duyulmaz. Bunun yanı sıra, gerekli programlar kullanılarak kalçanın üç boyutlu görüntüsü de elde edilebilir.

Tönnis tarafindan 1987'de sunulan radyolojik ölçütler oldukça geniş kabul görmüştür. Buna göre, normal bir eklem yüzeyinin sferik ve konsantrik uyumlu olması gerekir. Eklem yüzeylerinin paralel olup femur başının sferisitesinin bozulması durumunda patolojik uyum söz konusudur. Bir kalça ekleminin uyumsuz olmasından ise, asetabular çatının şeklinin femur başı şeklinden tamamen farklı olması anlaşılır. ${ }^{[7]}$ Buna göre; Evre 1 'de eklem yüzleri normal uyumlu, Evre 2'de femur 
başının tam örtülmesi ile birlikte patolojik uyum, Evre 3'te femur başının tam örtülememesi ile birlikte patolojik uyum, Evre 4'te ise tam uyumsuz kalça eklemi görülür. Eklem dejenerasyonu en fazla Evre 4'te oluşur.

Harris ve Lloyd-Roberts ise uyumlu kalçayı şu şekilde özetlemişlerdir: alt ekstremiteler birbirine paralelken pelvik oblisite olmaması, Shenton hattında kırılma olmaması ve her iki tarafta femur başı merkezlerinin orta hatta eşit mesafede bulunması. ${ }^{[8]}$

\section{DOĞAL SEYIR}

GKD tedavi edilmediğinde değişik klinik varyasyonlar oluşabilir; kalçada erken yaşta total endoprotez ameliyatı gerektirecek ileri derecede ağrı ve hareket kısıtlılığına neden olan sublukse kalça zemininde koksartrozdan, aksayarak yürüme dışında ağrıya neden olmayan tam çıkık olgularına kadar geniş bir yelpazede olgular görülür.

Tam çıkık olgularında seyir iki değişkenin varlığına bağlıdır: iyi gelişmiş bir yalancı asetabulum ve bilateral olma. ${ }^{[2]}$ Yalancı asetabulum olmadığında, çoğu hastada eklem hareket açıklığının iyi olduğu ve hafif derecede fonksiyonel yetersizlik olduğu görülür. İyi gelişmiş bir yalancı asetabulum olduğunda ise dejeneratif eklem hastalığı gelişerek klinik sonuçlar kötüleşir. Yalancı asetabulumun hangi şartlarda geliş̧tiği ise bilinmemektedir. ${ }^{[3]}$

Bilateral dislokasyonlarda bel ağrısı oluşabilir. Bu ağrının, bilateral dislokasyonlarla ilişkili olan hiperlordoza ikincil olduğu düşünülmektedir.

Tek taraflı dislokasyonlarda ise bacak boy eşitsizliğine ikincil gelişen sorunlar, ipsilateral diz deformitesi ve ağrı, skolyoz ve yürüme bozuklukları sık görülür. $\mathrm{Bu}$ hastalarda, kalçada gelişen fleksiyon-adduksiyon deformitesi, dizde valgus deformitesine neden olabilir. Valgus diz deformitesinde genellikle mediyal kollateral bağda zayıflık ve lateral eklem aralığında dejeneratif eklem hastalığı görülür.

Radyolojik olarak, asetabular displazi ve subluksasyon arasındaki fark, Shenton hattının bütünlüğüne göre değerlendirilir. Subluksasyonda Shenton hattı bozulmuştur ve femur başı superior, lateral ya da superolateral doğrultuda asetabulumun mediyal duvarından uzaklaşmıştır. Displazi de ise Shenton hattı bozulmamıştır. GKD tedavisi sonrası rezidüel subluksasyon, dejeneratif eklem hastalığı ve klinik kötü sonuç ile sonuçlanır. ${ }^{[3]}$ Subluksasyon ve hastanın yaşı arttıkça, dejenerasyon da artar. Radyolojik olarak displazik kalçaların da, özellikle kadınlarda, dejenerasyonla sonuçlanacağı gösterilmiştir. ${ }^{[2]} \mathrm{Bu}$ dejenerasyon muhtemelen mekanik kaynaklı olup uzun süreli artmış kontakt basınca bağlıdır. Aşırı yüklenme, kötü uzun dönem sonuçlarla ilişkilidir (2 megapascalın üzerinde uzun süreli basınç hasara yol açar $\left.{ }^{[5]}\right)$. Aseptik nekroza bağlı asferik femur başları daha fazla noktasal basınca maruz kalır. Radyolojik dejeneratif eklem hastalığının aşırı yüklenmenin miktarı ve süresi ile bağlantılı olduğu sonucu çıkmaktadır. Bu aşııı yüklenme, çok genç yaşta asetabular kenar sendromuna yol açabilir. ${ }^{[3]}$

Asetabular displazi klinik olarak sessiz olabilir ve rastlantısal olarak ya da semptomlar oluşmaya başladıktan sonra saptanabilir.

Kalça dejeneratif artritinin \%20-50'sinin subluksasyona ya da residüel displaziye ikincil geliştiği tahmin edilmektedir. ${ }^{[3]}$ Wiberg, CE açısındaki azalma ile ölçülen displazi miktarı ile radyografik olarak saptanan dejenerasyonun doğru orantılı olduğunu bildirmiştir. Wiberg'in serilerinde, CE açısı küçüldükçe asetabular displazinin ve subluksasyon riskinin arttığı, subluksasyonun dejeneratif eklem hastalığında asıl etmen olduğu gösterilmiştir. ${ }^{[9]}$

Semptomlar başladığında radyografik olarak tek bulgu, yük taşıma alanındaki skleroz artışı olabilir. Sklerozun nedeni, azalan yük taşıma alanına ve birim alan başına düşen stresin artmasına yanıt olarak, artan osteoblastik uyarıdır.

Sublukse kalçalarda semptomların başlama yaşı disloke kalçalara göre daha küçüktür. Harris, asetabular displaziye ikincil dejeneratif eklem hastalığında semptomların erken yaşta başladığını ve serisindeki hastaların \%50'sinin ilk rekonstrüksiyon ameliyatını 60 yaşından önce olduğunu bildirmiştir. ${ }^{[5]}$

\section{TEDAVi}

GKD tedavisinde amaç, hasta yaşına bakılmaksızın aynıdır. Birinci amaç, femur başı ve asetabulumun uygun şekilde gelişimine uygun ortamı oluşturmak amacıyla redüksiyonu sağlamak ve korumaktır.. ${ }^{[5]}$ Birçok çalışmada, redüksiyon sağlanıp korunduğunda asetabalumun uzun yıllar boyunca gelişme potansiyeli olduğu gösterilmiştir. ${ }^{[3,4]}$ Femur başı ve anteversiyonu da remodele olabilir. ${ }^{[5]}$ GKD tanısı ne kadar geç konulursa bu amaçlara ulaşmak o kadar zorlaşır. Asetabular ve femoral remodelizasyon potansiyeli azalır ve tedavi daha karmaşık hale gelir. Yaş arttıkça ve tedavi daha karmaşık hale geldikçe, dejeneratif eklem hastalığı gelişme riski de artar. Matüriteye ulaşıldığında, dejeneratif eklem hastalığını önlemek için radyografik olarak normal bir kalça oluşması amaçlanır. Rezidüel asetabular displazi varlığında subluksasyon olmasa bile sonuçta dejeneratif eklem hastalığı gelişeceği gösterilmiştir; bu nedenle asetabuler displazi ve subluksasyon da kabul edilemez. ${ }^{[2]}$ 
On sekiz aydan büyük çocuklarda ligamentum teres uzamış ve kalınlaşmış, kapsül yukarı doğru uzamış ve iliopsoas tendonunun asetabulum girişini daraltması sonucu kum saati deformitesi oluşmuştur. Transvers asetabular bağ ve inferior kapsül kalınlaşarak asetabulum hacmini daraltmıştır. Bu durumda kapalı redüksiyonla başarı sağlama ihtimali düşüktür; bu nedenle ideal tedavi açık redüksiyondur. Anestezi altında kapalı redüksiyon sağlansa bile, yumuşak doku interpozisyonu olacak kalça instabil olacağından, aşırı abduksiyon ve iç rotasyonda alçılama yapılması gerekecek ve bu da komplikasyon oranını arttıracaktır. Açık redüksiyon altın standart olarak kabul edilmesine rağmen, Morin ve arkadaşları, 1,5-5 yaş arası Tönnis Evre 3 ve 4 GKD olgularına uyguladıkları uzun süreli traksiyon, tedrici kapalı redüksiyon ve Salter innominat osteotominin 30 yıllık sonuçlarını 2011 yılında yayınlamış ve sonuçlarının \%80 olguda mükemmel olduğunu, avasküler nekroz oranının açık redüksiyon serileri ile eşit olduğunu (\%6) bildirmişlerdir. ${ }^{[10]}$

Açık redüksiyonun amacı; redüksiyonu sağlamak ve sürdürmek, femur başında oluşabilecek hasarı önlemek ve proksimal femur ve asetabulumun gelişimi için optimal ortamı sağlamaktır. Açık redüksiyon değişik yaklaşımlarla gerçekleştirilebilir.

Bu yaş gurubunda en sık kullanılan yaklaşım, anterolateral Smith-Peterson yaklaşımının Salter ve Dubos tarafından tanımlanan "bikini" modifikasyonudur. Bu yaklaşımda, sartorius ve tensor fasya lata kasları arasından girilerek rektus femoris kasının uzun başı serbestleştirilir, yine rektus femoris kasının reflekte başı altından kapsüle ulaşılır. Redüksiyonun başarıIı olması için redüksiyona engel olan ekstraartiküler ve intraartiküler yapıların uzaklaştırılması gerekir. Ekstraartiküler yapılar; adduktor ve iliopsoas kaslarının spazmıdır. Kalçanın sublukse ya da lukse pozisyonundan dolayı bu kaslarda zamanla kısalık gelişir. Açık redüksiyon öncesinde genellikle adduktor longus ve iliopsoas gevşetilir. Redüksiyona engel olan intraartiküler yapılar ise; uzamış ve kalınlaşmış ligamentum teres, hipertrofik transvers asetabular ligament, asetabulum tabanını dolduran pulvinar ve en önemlisi de anteromediyal kapsülde daralma ve kalınlaşmadır. Hipertrofik ligamentum teres nedeniyle asetabular çap azalmıştır. ${ }^{[11,12]}$

Redüksiyon sırasında nadir görülen bir oluşum da inverte olmuş hipertrofik labrumdur. Bu oluşuma limbus adı da verilir. Başarısız kapalı redüksiyon denemelerini takiben asetabular labrum iyatrojenik olarak inverte olmuş olabilir ve redüksiyona engel teşkil edebilir. Bu oluşumun operasyon sırasında rezeke edilmesi asetabular gelişimi bozar. Eğer operasyon sırasında cerrah bu dokunun redüksiyona engel olduğunu düşünüyorsa radyal kesilerle genişletilebilir ancak rezeke edilmemelidir. ${ }^{[2,4]}$ Limbusun kıkırdağı birincil olarak anormal ya da travmatik açık veya kapalı redüksiyonlar sırasında hasar görmüş olabilir. Bu hasara karşı oluşan yanıt, aksesuvar ossifikasyon merkezlerinin oluşumundan sorumlu olabilir. ${ }^{[9]}$

Anterolateral yaklaşım ile, superior ve laterale uzamış olan kapsül rezeksiyon ve pilikasyon yapılarak daraltılabilir. Pelvik osteotomi gerekiyorsa aynı yaklaşımla uygulanabilir. Bu yaklaşımın avantajlarından birisi de kalçanın fonksiyonel pozisyonda alçılanmasına olanak tanımasıdır. Aşırı abduksiyon ve iç rotasyonda alçılamanın neden olduğu femur başı avasküler nekrozu riski azaltılmış olur. Pelvik osteotomi yapılmadığında alçı 8-12 hafta arası tutulur, beraberinde pelvik osteotomi yapıldığında ise alçı süresi kısalır.

Anterolateral yaklaşımın dezavantajarı; mediyal ve anteromediyal yaklaşımlara göre daha fazla kan kaybına neden olması, iliak apofiz ve kalça abduktor kaslarında hasara neden olabilmesi, lateral femoral kutanöz sinir hasarı ve ameliyat sonrasında eklem sertliğine neden olabilmesidir. Bilateral olgularda, iki ameliyat arasında 2-6 hafta ara olması önerilir. ${ }^{[11,12]}$

Mediyal yaklaşımların avantajı, redüksiyona engel olan oluşumların direkt üzerinden yapılmasıdır. Ferguson, mediyal yaklaşımı adduktor brevis ve adduktor magnus arasından gerçekleştirilir. ${ }^{[2]}$ Avantajları; minimal yumuşak doku diseksiyonu gerektirmesi, mediyal eklem kapsülüne ve iliopsoas tendonuna direkt görüş sağlaması, iliak apofiz ve kalça abduktor kaslarda hasara yol açmaması, minimal kan kaybı ve mükemmel kozmetik sonuç elde etmesidir. Ancak, bu yaklaşımlar birçok cerrah için teknik olarak daha zordur; kalça eklemi derinde olduğu için görüş zor olabilir, kapsül tamiri bu girişimle yapılamaz. Redüksiyonun stabilitesi ancak alçı ile sağlanabilir. Yaşı büyük hastalarda uygulanması daha zordur ve gerektiğinde ikincil girişimler (pelvik osteotomi) aynı insizyondan gerçekleştirilemez. Ayrıca, bu yaklaşımla daha yüksek oranda proksimal femur büyüme bozukluğu (avasküler nekroz) olabileceği bildirilmiştir. ${ }^{[13]}$

Weinstein ve Ponseti tarafından modifiye edilmiş anteromediyal Ludloff yaklaşımı, femoral nörovasküler demet ile pektineus kası arasından yapılır. ${ }^{[2]}$ Redüksiyona engel olan oluşumlara ulaşmak amacıyla yapılabilecek en direkt yaklaşımdır. Minimal kan kaybına neden olur. Sadece adduktor longus ve iliopsoas serbestleştirilir sonrasında direkt kapsüle ulaşılır. Aynı seansta her iki kalçaya da redüksiyon yapılabilir. iliak apofizde ve kalça abduktor kaslarında hasara neden olmaz, kalçada eklem sertliği yapmaz ve mükemmel kozmetik sağlar. Ancak, aynı yaklaşımla ikincil 
girişimler yapılamaz, çoğu cerrah açısından teknik olarak zordur, kalça eklemi derinde olduğundan görüş zor olacağı için büyük çocuklarda uygulanması zordur. Kapsüler plikasyon yapılamaz. Proksimal femurun birincil dolaşımını sağlayan mediyal femoral sirkumfleks damarlar görüş sahasının içindedir ve zarar görebilir. Anterolateral yaklaşıma göre daha yüksek avasküler nekroz oranı bildirilmiştir. ${ }^{[13]}$ Ancak öğrenme eğrisi tamamlandıktan sonra mükemmel görüş sağlandığını ve aseptik nekroz oranının düşük olduğunu bildiren yayınlar da vardır. [13] ikki yaşından küçük çocuklarda, kapsüler plikasyon yapılmasa bile başarılı bir redüksiyon sonrası yeterli süre alçı ile takip edildiğinde kapsülün gerginleştiği, ayrıca cerrahi girişime bağlı skar dokusunun da kapsüler stabiliteye destek olduğu gösterilmiştir. ${ }^{[11]}$ Ameliyat sonrasında eklemde kısıtlılık yapmaz ve mükemmel kozmetik sonuç sağlar.

Asetabuler osteotomi yapılmadan sadece açık redüksiyon yapıldığında redüksiyon 8-12 hafta alçı ile korunmalıdır. Altı hafta ilk alçı tutulduktan sonra anestezi altında bu alçı değiştirilir ve abduksiyon ve fleksiyon azaltılarak ve eklem hareketleri kontrol edilerek ikinci alçı uygulanır. Alçı çıkarıldıktan sonra da 1,5 ay boyunca 23 saat abduksiyon cihazı kullanılır daha sonra grafilerle asetabular gelişim kontrol edilerek abduksiyon cihazı geceleri kullanılmaya devam edilir. Mediyal açık redüksiyon yapılan olgularda kapsüler plikasyon yapılamadığından alçı sonrası daha rijid abduksiyon cihazları ile takip yapılması önerilmektedir. ${ }^{[2]}$

Açık redüksiyon sonrasında grafiler ile asetabulum gelişimi değerlendirilirken aksesuvar ossifikasyon merkezlerinin varlığına dikkat edilmesi önemlidir. Asetabulum periferinde neolimbus bölgesindeki kıkırdakta aksesuvar ossifikasyon merkezlerinin varlığı, cerraha asetabular gelişim ve kıkırdağın ossifikasyon potansiyeli hakkında fikir verebilir. Aksesuvar ossifikasyon merkezleri saptandığında cerrah ikincil asetabular osteotomi yapmak için beklemeyi seçebilir. ${ }^{[2,5]}$

íki yaşından küçük çocuklarda, redüksiyon sonrasında asetabulumun gelişme potansiyeli yüksek olduğundan, aynı seansta asetabular ve proksimal femoral osteotomiler yapılmayabilir. Redüksiyon sonrasında asetabulumun gelişme potansiyeli mükemmeldir ve dört yaşına kadar daha fazla olmak kaydıyla sekiz yaşına kadar devam eder. ${ }^{[2,5]}$ Asetabular indeks, gözyaşı figürünün oluşumu ve asetabulum mediyal duvarının incelmesi gibi parametreler ile ölçüldügüunde, asetabulumun gelişimindeki en hızlı değişikliğin ameliyat sonrasındaki ilk 18 ayda olduğu görülür. ${ }^{[2]}$ Bu süre içinde femoral anteversiyon ve koksa valga gibi proksimal femurdaki deformiteler de mükemmel şekilde düzelebilir. Ancak asetabular gelişimin giderek azalması nedeniyle, 18 ay sonrasında bütün hastalarda açık redüksiyona pelvik osteotomi eklenmesi gerektiği görüşü de yaygın kabul görmektedir.

Femoral kısaltma, kalça eklemi üzerindeki yumuşak doku gerginliğini etkin bir şekilde azaltır. Açık redüksiyon öncesi yapılan traksiyonun yerini almıştır. Genellikle iki yaşından sonra uygulansa da aşırı yumuşak doku gerginliğinin olduğu daha küçük olgularda da uygulanabilir. Lateral yaklaşımla proksimal femur ortaya konulur ve subtrokanterik osteotomi yapilır. Kalça redükte edildikten sonra, proksimal ve distal parçalar yan yana konulduğunda üst üste binen kısım, kısaltılması gereken uzunluğu gösterir. Vallamshetla ve arkadaşları gereğinden fazla kısaltma yapmanın gereğinden az kısaltmaktan daha iyi olduğunu belirtmişlerdir. ${ }^{[14]}$ Koksa valga ve aşırı anteversiyon varsa, varizasyon ve derotasyon da yapılabilir. Osteotomi plak ve vidalarla sabitlenir. Üç yaşından büyük çocuklarda, proksimal femur üzerindeki basıncı azaltmak amacıyla yapılan femoral kısaltmanın avasküler nekroz oranını operasyondan önce uygulanan traksiyona göre daha etkili bir şekilde azalttığı gösterilmiştir. ${ }^{[14,15]}$ Açık redüksiyon sırasında yapılan femoral kısaltmanın avantajı, kısaltmaya ek olarak anteversiyonu ve valgusu düzeltecek derotasyon ve varizasyon işleminin de ihtiyaca göre gerçekleştirilebilmesidir. Dezavantajı ise ikinci bir insizyon ve internal tespit gerektirmesi ve kullanılan materyalin çıkarılması için bir ameliyat daha gerektirmesidir. Femoral kısaltma için 2-3 yıl arası gri zon olarak değerlendirilmektedir. Bu dönemde bazı kliniklerde hala traksiyon uygulansa $\mathrm{da}^{[10]}$ altın standart kısaltma osteotomisidir. ${ }^{[14]}$

On sekiz aydan büyük çocuklarda asetabulumun remodelizasyon potansiyeli azaldığından çoğu cerrah rutin asetabular osteotomi yapılmasını tercih etmektedir. Açık redüksiyona ek olarak yapıldığında kalçanın güvenli zonunu arttırır. Operasyon sırasında stabiliteyi kontrol ederek asetabular osteotomi yapmak için beklemeyi tercih eden cerrahlar da vardır. ${ }^{[5]}$ Eğer operasyon sırasında stabilite yeterli bulunursa asetabular gelişim için birkaç yıl beklenebileceği ve eğer radyografik olarak asetabulumda gelişme saptanmıyorsa pelvik osteotominin o zaman yapılabileceği de bildirilmiştir. ${ }^{[2,5]}$ Genellikle, daha iyi sonuçlar alındığından ve daha az komplikasyon geliştiğinden, beklemek yerine asetabular osteotomi erken yapılmaktadır. Pelvik osteotomi yapıldığında femur başı ve asetabulum arasında temas alanı artar böylece displastik asetabulumun ucundaki noktasal yüklenme azalmış olur. Kalça çevresi kaslarda ve kapsülde gevşeme sağlanır ve abduktor moment kolu iyileşir. Kalça abduktor ve fleksör kaslarının gerginliği artar. ${ }^{[16]}$

Bu yaş grubunda en sık tercih edilen süreç, açık redüksiyon ve Salter innominate osteotomisi ${ }^{[17-19]}$ ya da 
Pemberton osteotomisidir. ${ }^{[20,21]} \mathrm{Bu}$ yaş grubunda asetabulumdaki yetmezlik genellikle anteriordadır ve her iki osteotomi de anterior kapsamayı arttırır. Wang, 2014 yılında yaptığı radyolojik çalışmada, Pemberton osteotomisi ile Salter osteotomisine göre daha fazla anterior örtünme sağlanacağını göstermiştir. ${ }^{[17]}$ Standart olarak Smith-Peterson anterolateral yaklaşımının Salter modifikasyonu kullanılır. Böylece kapsüler plikasyon yapılabilir, kalça daha fonksiyonel pozisyonda alçılanabilir ve aynı yaklaşımla pelvik osteotomi de yapılabilir.

íki-üç yaşlarından sonra genellikle açık redüksiyon ve asetabular osteotomiye femoral kısaltma da eklenir. Açık redüksiyon, pelvik osteotomi, femoral kısaltma ve derotasyon ameliyatlarının birlikte yapılmasına, tek basamaklı kombine cerrahi girişim adı verilir. Bu girişim ile, daha büyük yaştaki hastaların tedavisinde iyi sonuçlar bildirilmiştir. ${ }^{[22,23,11]}$ Papavasiliou, 10-17 yaş arası erişkinlerde uyguladığı kombine ameliyatlarla başarılı sonuçlar bildirmiştir. ${ }^{[22]}$ El-Tayeby, 8-18 yaş arasında 19 hastaya tek basamaklı kombine girişim uygulamış, pelvik osteotomi olarak Salter ya da üçlü osteotomi kullanmış ve hastalarda ihtiyaca göre $5 \mathrm{~cm}$ 'ye kadar kısaltma gerçekleştirmiştir. Ileri yaşta tedavi edilmemiş olguların gelişmekte olan ülkelerde görüldüğünü belirttiği serisinde, radyolojik Severin kriterlerine göre \%84 mükemmel ve iyi sonuç aldığını, yanlız bir hastada avasküler nekroz geliştiğini bildirmiştir. ${ }^{[15]}$
Femoral anteversiyon artışı klinik olarak da saptanabilir; ancak, en doğru şekilde BT ile ölçülür. Asetabular displazinin üç boyutlu BT ile değerlendirilmesi kıkırdak yapı görülemeyeceğinden çocuklardan ziyade erişkinlerde kullanılabilir. Erişkinlerde asetabular displazi en iyi üç boyutlu BT, pelvis AP grafi ve yalancı profil grafisi ile değerlendirilir (Şekil 5).

GKD hastalarında femoral boyun şaft açısı genellikle normaldir; ancak, femoral anteversiyon arttığından radyografik olarak Shenton hattında bozulma olur ve sublukse görüntü oluşur. Redüksiyon sağlandıktan sonra genellikle femoral anteversiyon kendiliğinden düzelir. ${ }^{[3]}$ Shenton hattı bozulduğunda proksimal femurun asetabulum ile uyumu derotasyon osteotomisi ile sağlanabilir. Gerektiğinde varizasyon da eklenebilir. El-Tayeby, varizasyonun Trendelenburg topallamasına yol açacağını ve kısaltma ve derotasyona eklenmemesini savunmuştur. ${ }^{[15]}$ Teorik olarak femur başının asetabulum içine yönlendirilmesinin normal asetabular şekillenmeyi uyaracağı düşünülse de, varus derotasyon osteotomisi nadiren tek başına kullanılır. Bu durumda osteotomi dört yaşından önce yapılmalıdır çünkü sekiz yaşından sonra tek başına bu operasyonla asetabular displazinin düzelmesinde bir yarar sağlanamaz. ${ }^{[3-5]}$

Varus derotasyon osteotomisi yapılmadan önce femur başının konsantrik redüksiyonunu konfirme

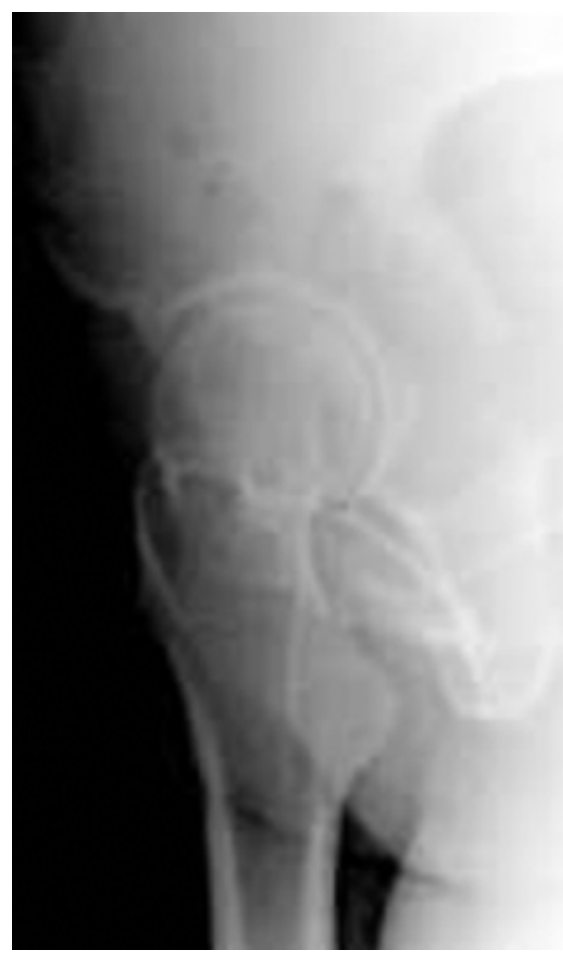

Şekil 5. Yalancı profil grafisi.

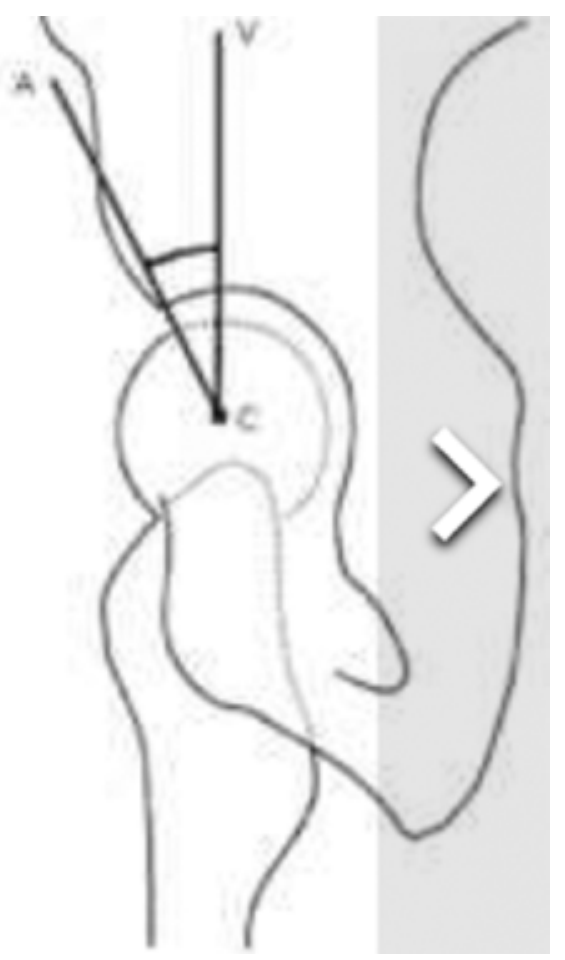


etmek için hastanın $30^{\circ}$ abduksiyon ve maksimum iç rotasyonda pelvis AP grafisi çekilir. Bu pozisyonda femur şaft boyun açısı doğru şekilde görüntülenebilir. Eğer konsantrik redüksiyon elde edilemezse açık redüksiyon ve pelvik osteotomi eklenmelidir.

Küçük çocuklarda varus osteotomisinden kaynaklanacak kısalık, büyümenin uyarılması ve normal şaft boyun açısının restorasyonu ile düzelir. Erişkinlerde ise boyun şaft açısının $15^{\circ}$ den fazla azalması ekstremitede kısalmaya yol açar. Varizasyonun fazla yapılması şaftın lateralizasyonuna, mekanik aksın dizin mediyaline kaymasına ve sonuçta dizde mekanik sorunlara yol açar. Bu nedenle genellikle varizasyon tercih edilmez. [24] Proksimal femur osteotomisi yapıldığında kullanılan malzeme genellikle $12-18$ ay sonra çıkartılır.

\section{GKD’DE PELVIK OSTEOTOMILERIN ROLÜ}

Konsantrik redüksiyon sağlanıp anatomik redüksiyon korunduğunda asetabular gelişmenin sekiz yaşına kadar devam ettiği gösterilmiştir. ${ }^{[3-5]} \mathrm{Ne}$ var ki, dört yaşından sonra normal anatomiyi restorasyon potansiyeli belirgin şekilde azalır. ${ }^{[4]}$

Rezidüel asetabular displazinin düzeltilmesi femur başı için daha iyi bir yük taşıma alanı oluşturur, kalçanın normal biyomekaniğini restore eder ve temas basıncını azaltır; dejeneratif eklem hastalığının oluşumunu engelleyerek kalçanın ömrünü uzatır. ${ }^{[25]}$

Rezidüel displazisi olan redükte kalçalarda sorunun asetabulumda yetmezlik değil, periferik asetabular kıkırdakta ossifikasyon bozukluğu olduğu bulunmuştur. Yeterli zaman verildiğinde bu asetabular kıkırdağın bir kısmı normal ossifikasyon sürecine girerek displazinin büyük bir bölümünü düzeltebilir. Ancak, açık ya da kapalı redüksiyon ile tedavi edilen hastaların çoğunda bu işlem gerçekleşmez ve asetabuluma kendi kendine düzelmesi için süre tanındıktan sonra girişimde bulunulması gerekir. ${ }^{[25]}$ iliak kemiğe yapılacak bir osteotomi ve bu osteotomi iyileşirken oluşacak neovaskülarizasyon, daha önce kemikleşememiş bu kıkırdağı uyararak kemikleşmesini sağlayabilir. Asetabulumun yeniden yönlendirilmesi ile daha normal bir kemiksel anatomi ve biyomekanik sağlanır, bu etmenler de kıkırdağın reossifikasyonunu uyarabilir. ${ }^{[3]}$

ìki çeşit pelvik osteotomi vardır: rekonstrüktif osteotomiler ve kurtarma (salvage) prosedürleri. Rekonstrüktif prosedürler eklem yüzeyini hiyalin kıkırdak ile restore eder, kurtarma prosedürlerinde ise eklem kapsülünün fibröz metaplazisi ile femur başı örtünmesi sağlanır. ${ }^{[16,26]}$

Geleneksel olarak pelvik osteotomiler dört gruba ayrılır: ${ }^{[2,25,27]}$

\section{Grup 1}

Asetabulumun yönelimini bir bütün olarak değiştiren rotasyonel osteotomilerdir. İnnominat kemik boyunca tam kat kesi yapılır ve osteotomi hattı kaynayıncaya kadar iki adet K-teli ya da vidalarla stabilize edilir. Bu şekilde femur başı asetabular eklem kıkırdağı ile örtülmüş olur. Asetabulum anteriora, inferiora ve laterale yer değiştirir ancak asetabulumun posteriorunda yetmezlik oluşturacağı unutulmamalıdır. Bu osteotomiler; Salter innominate osteotomisi, Shuterland çiftli innominat osteotomisi, Tönnis, Steel ve Ganz'ın üçlü innominat osteotomileri ile Wagner ve Eppright'ın sferik osteotomileridir. ${ }^{[2,27]}$ Rotasyonel osteotomiler için ön şartlar; tam konsantrik redüksiyon sağlanmış olması, kalça adduktorlarını ve iliopsoası içeren kas kontraktürlerinin gevşetilmiş olması, asetabulum ve femur başı arasında tam uyum olması ve eklem hareket açıklığının iyi olmasıdır. Subluksasyon varlığında yapılacak olan rotasyonel osteomiler femur başının ciddi hasarı ile sonuçlanır. ${ }^{[27]}$

Salter innominat osteotomisi, simfizis pubisi kaldıraç olarak kullanarak düzelme sağlar ve en çok simfizis pubisin henüz esnek olduğu 18 ay -6 yaş arasında kullanılır; ancak, erişkinlerde de uygulanabilir. ${ }^{[19]}$ Salter innominat osteotomisi en çok CE açısının $10^{\circ}$ 'nin üzerinde olduğu hastalarda başarılı sonuç verir. Yaklaşık 20-25 lateral örtüm, $10-15^{\circ}$ kadar da anterior örtüm sağlayabilir (Şekil 6). ${ }^{[18]}$ Yapılan tam kat innominat osteotomi sonucu hem asetabular hem de femoral bölgede kanlanma artar ve bu artış üç ay sürer. Kanlanmadaki bu artış, osteotominin iyileşmesi sırasında kollateral dolaşımın artmasına bağlanmaktadır. Her ne kadar Mac Ewen ve Utterback innominat osteotomi sonrasında femur başının kanlanmasının bozulacağını ileri sürmüşlerse de, Kasselt ve Shim'in yaptığı çalışmalar, osteotomi sonrası femur başı kanlanmasının \%50-56 arasında arttığını göstermiştir. ${ }^{[2]}$ Bu yönüyle innominat osteotomi Perthes hastalığında da uygulanmaktadır. ${ }^{[2]}$

Sutherland ve Moor'un çiftli innominat osteotomisi, ek olarak pubisi osteotomize ederek daha fazla rotasyon sağlamayı hedefler. Ancak spermatik kord, mesane ve üretra hasarı gibi ciddi komplikasyonları vardır. ${ }^{[25]}$

Üçlü innominat osteotomiler iliak osteotomi yanında hem pubisi hem de iskiumu osteotomize ederek daha fazla örtünme sağlamayı amaçlar ve daha büyük hastalarda kullanılabilir. ${ }^{[27]}$

Asetabular displazi rotasyonel bir osteotomi ile düzeltileceğinde, düzeltilmesi gereken displazi miktarı önem taşır. Salter osteotomisi ile sağlanacak örtünme miktarı kısıtlıdır ancak her üç pelvis kemiğini de kesen üçlü osteotomiler ile daha geniş örtünme sağlanır. ${ }^{[26]}$ 

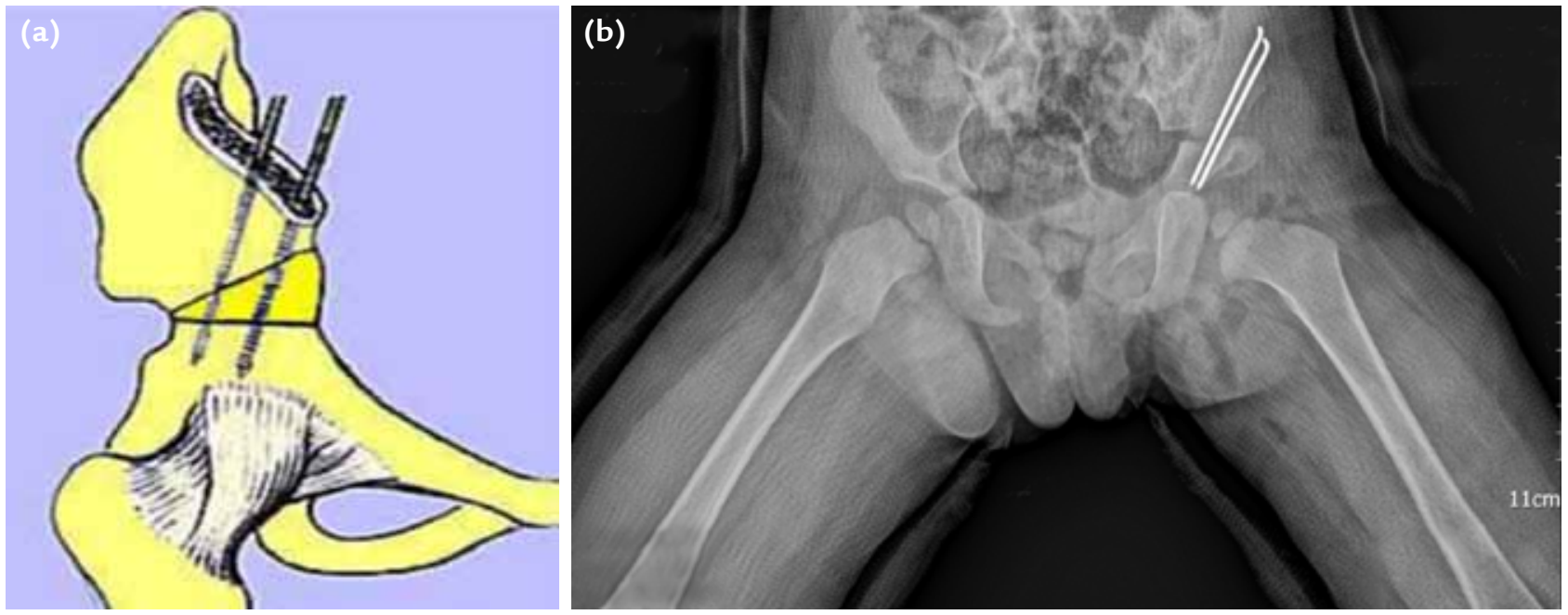

Şekil 6 a, b. Salter innominat osteotomisi.

Osteotomi asetabuluma ne kadar yakından yapılırsa o kadar çok düzelme sağlanır. Ganz ve Tönnis tarafından tanımlanmış olan üçlü osteotomiler, Steel üçlü osteotomisine göre daha fazla örtünme sağlarlar. Asetabuluma en yakın olan Eppright, Wagner ve Naito prosedürleri en büyük düzelmeyi sağlarlar ancak teknik olarak deneyim gerektirirler ve daha yüksek komplikasyon riski taşırlar. ${ }^{[2]}$

Periasetabular Ganz osteotomisi teknik olarak en zor ameliyattır. Pubis, ilium ve iskium osteotomilerine ek olarak, siyatik çentiğin yaklaşık $1 \mathrm{~cm}$ anteriorundan asetabulum posterior kolonundan transvers bir osteotomi yapılarak iliak ve iskial kesiler birleştirilir. Asetabulumu çok iyi mobilize eder, mükemmel örtüm ve osteotomi siyatik çentiğe girmediğinden iyi stabilite sağlar. Ayrıca, hastanın erken yük vermesine olanak verir (Şekil 7). ${ }^{[27]}$ Osteotomi hattı triradiat kıkırdaktan geçtiği için bu yapının açık olduğu çocuklarda uygulanamaz.

\section{Grup 2}

Asetabuloplasti prosedürlerini içerir. Burada triradiat kıkırdağa kadar inkomplet osteotomi yapılarak, kaldıraç kolu olarak triradiat kıkırdağın farklı bölgeleri kullanilır. Pemberton ve Dega osteotomileri, asetabuloplasti
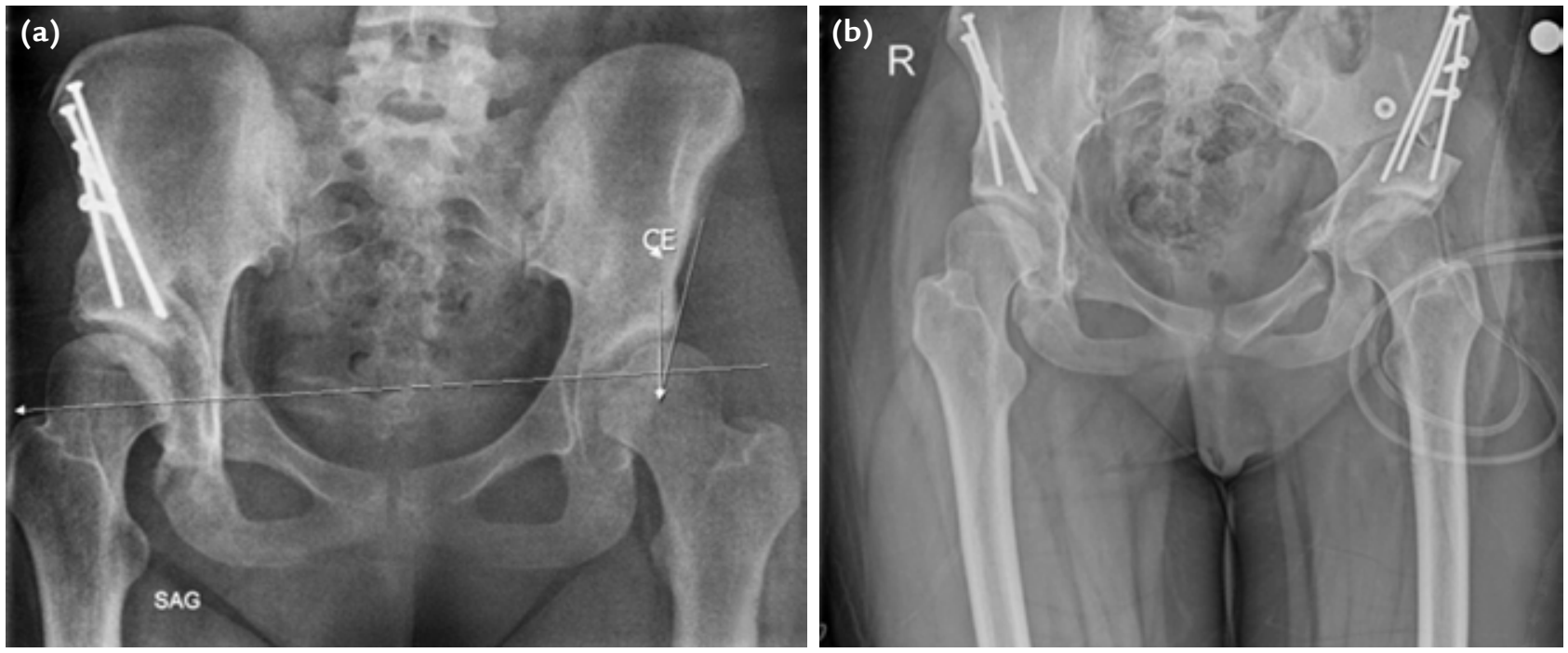

Şekil 7. a, b. Otuz beş yaşında bayan hastanın sol kalçasında ameliyat öncesi displazi mevcut (a). Ganz periasetabular osteotomi sonrası displazinin düzeldiği görülüyor (b). 

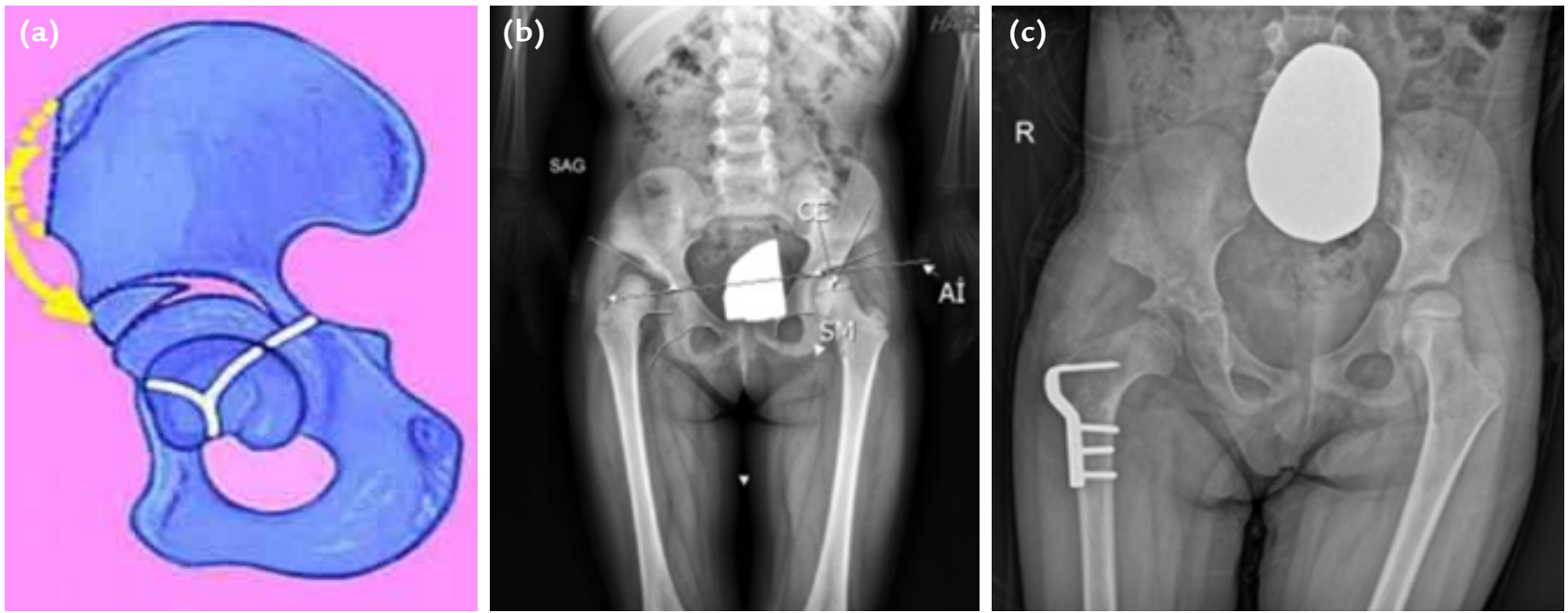

Şekil 8. a-c. Pemberton osteotomisi (a). Otuz altı aylık kız çocuğunda sağ GKD mevcut (b). Sağ kalçaya yapılan Pemberton osteotomisi görülüyor (c).

prosedürleridir. Bu prosedürler triradiat kıkırdağı kaldıraç kolu olarak kullandığından teorik olarak asetabulum hacmini küçültür. Asetabulum hacmini küçülttüğü için de sığ ve geniş asetabulumlarda tercih edilir. Konsantrik redükte olan kalçalarda 2-10 yaş arası kullanılır. Osteotomi hattı siyatik çentiğe girmediğinden stabil kabul edilir ve greft konulduktan sonra K-telleri ile tespit gerektirmez. ${ }^{[25-27]}$ Asetabulum hacmini azalttığından femur başı üzerindeki basıncı arttırmaması için genellikle femoral kısaltma da prosedüre eklenir. ${ }^{[2]}$

Pemberton osteotomisinde, eklem kapsülünün yaklaşık $1 \mathrm{~cm}$ üzerinden başlayarak iliumun iç ve diş tabulaları boyunca siyatik çentiğe girmeden triradiat kıkırdağın ilioiskial bacağına doğru bir kesi yapılır. İç ve dış tabula kesileri modifiye edilerek lateral ve anterior örtüm miktarı ayarlanabilir (Şekil 8). ${ }^{[2,12,27]}$ Chang, Pemberton osteotomisinden sonra erişkinlerde ameliyatlı tarafta sağlam tarafa göre daha fazla eklem yüklenmesi olduğunu saptamıştır; bu nedenle de avasküler nekroz riskinin artabileceğini belirtmiştir. ${ }^{[28]}$ Dega prosedüründe ise osteotomi sadece iliumun dış tabulası boyunca yapılır. Siyatik çentiğe girmeden triradiat kıkırdağa doğru yönlenilir. Greftin konulacağı bölgeye göre posterior ve lateral örtünme sağlanabilir. Dega, daha çok posterior asetabular yetmezliğin olduğu nöromusküler hastalıklarda tercih edilir. Karlen ve arkadaşları, Dega osteotomisinin versatil bir osteotomi olduğunu ve destek aldığı noktaya göre hem anterior hem lateral hem de posterior kapsamayı arttırabileceğini belirtmişlerdir (Şekil 9). ${ }^{[29]}$

Bu ameliyatlar triradiat kıkırdak kapandıktan sonra yapılamaz; triradiat kıkırdağa hasar verebilir ve erken kapanmasına neden olabilir; ancak bu komplikasyonlar sık görülmez. ${ }^{[2]}$

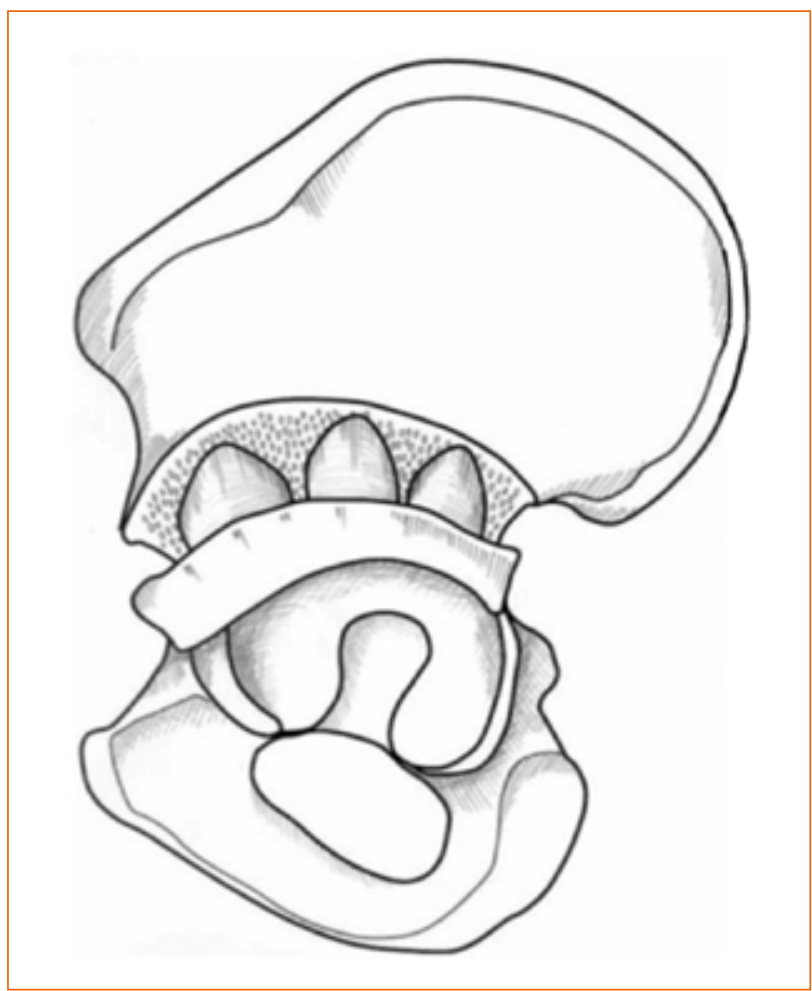

Şekil 9. Dega osteotomisi.

\section{Grup 3}

Asetabular rekonstrüksiyon prosedürleri; femur başının açıkta kalan bölümünde eklem kapsülünün üzerine kemik destek konulan prosedürlerdir. Femur başının örtünmesi kapsüler fibröz metaplazi ile sağlanır. Çeşitli "shelf" prosedürleri ve Chiari mediyal deplasman osteotomisi bu gruba örnek teşkil ederler. ${ }^{[2]}$ En sık kullanılan "shelf” prosedürü, geçmişte yaygın 
kullanılan Staheli "shelf” prosedürüdür ve hem tek başına hem de çeşitli rotasyonel osteotomilere destek olarak kullanılmıştır. Bu grup prosedürler kurtarma (salvage) ameliyatları olarak da anılırlar ve günümüzde birincil ameliyatlarda değil, gelişen komplikasyonların tedavisinde femur başı örtünmesinin ileri derecede eksik olduğu olgularda kullanılır. ${ }^{[2]}$ Özellikle femur başının sferik olmadığı ve femur başı ile asetabulumun uyumunun bozulmuş olduğu olgularda, erken dejeneratif değişikliklerin varlığında, artroplasti ihtiyacını geciktirmek ümidiyle uygulanır. Yük taşıma alanını genişleterek birim alana düşen stresi azaltarak dejenerasyonu yavaşlatacağı düşünülerek yapilır.

Chiari mediyal deplasman osteotomisi, simfizis pubis üzerine dayanarak distal parçanın mediyale ve $20^{\circ}$ yukarı deplase edildiği bir prosedürdür. Bu mediyalizasyon sonucu kaldıraç kolu kısalır ve eklem yüklenmesi azalır. Teorik olarak abduktor kas fonksiyonunun iyileşmesi beklenir. Bilateral Chiari osteotomisinin normal yolla doğum yapmayı engelleyeceği bildirilmiştir. ${ }^{[2,26]}$

\section{Grup 4}

Hibrid prosedürleri içerir. Bu grupta Salter ya da Pemberton osteotomisine eklenmiş "shelf" prosedürü örnek olarak verilebilir. Günümüzde uygulaması yoktur, tarihi önemi vardır.

Gerek Salter gerekse Pemberton tekniklerinin birbirine göre avantajlarının ve dezavantajlarının olması Westin ve Marifioti'yi bu iki osteotomiyi kombine etmeye yönlendirmiştir. Pembersal adı verilen bu teknikle her iki tekniğin avantajlarından yararlanarak asetabulumun reoryantasyonunu sağlamak ve bu esnada her iki tekniğin zorluklarını ve komplikasyonlarını en aza indirmek amaçlanır. ${ }^{[30]}$

Bu teknikte osteotomiye Pemberton gibi spina ili$\mathrm{ka}$ anterior inferior (SiAi) ve spina ilika anterior superior (SIAS) arasından başlanır ve kesi asetabulum domuna uygun eğri bir şekilde devam ettirilir; Y kıkırdağına kadar Pemberton gibi ilerlenir ve $Y$ kıkırdağı çaprazlanarak iskium cisminde bitirilir. Osteotomi hattı öne aşağıya ve laterale doğru açılırken burada yeşil ağaç kırığı oluşturulur. Bu boşluğa iliak kanattan alınan greft yerleştirilir. Bu modifikasyonun amacı, Salter gibi asetabulumun komplet reoryantasyonunun sağlanması ve Pemberton gibi asetabulum derinliğinin arttırılmasıdır. ${ }^{[2]}$ Bursalı, 44 kalçada yapılmış Pembersal osteotomisi sonuçlarını geriye dönük olarak incelemiş ve başarılı sonuçlar bildirmiş, ancak triradiat kıkırdakta erken kapanma riski diğer osteotomilere göre yüksek olduğundan, deneyimli cerrahlarca uygulanmasını önermiştir. ${ }^{[30]}$
Çakırgil; 1978 de SiAS'tan başlayarak trokanter majoru ortalayacak şekilde femur lateraline uzanan 1214 cm'lik kendi geliştirdiği insizyonu kullanarak dört yaşından büyük hastalarda bütün ameliyatları tek seansta yapmıştır. Adduktor tenotomi, anterior açık redüksiyon transilak pelvik osteotomi (Dega) ve femoral kısaltma derotasyon ve varizasyon ameliyatlarının hepsini tek seansta yaptığı bu tekniğe "radikal redüksiyon tekniği" adı verilmiştir. ${ }^{[31]}$

Asemptomatik hastada kalça displazisi saptandığında karar vermek zordur. Rastlantısal olarak radyografik minimal asetabular displazi saptanan asemptomatik erişkin hastalar için, aileyi olası erken eklem dejenerasyon olasılığı hakkında bilgilendirmek gerekir ve semptomlar gelişirse ameliyat düşünülmelidir; ancak, asemptomatik bir hastada radyografik olarak subluksasyon saptanırsa, semptomların başlamasını beklemeden cerrahi düzeltme yapılması dejeneratif eklem hastalığı gelişmesini önler. ${ }^{[4,5,32]}$

Semptomatik bir hastada artrit yokken ya da başlangıç dönemindeyken, eklem koruyucu ameliyatlar ile (Ganz, Naito, Steel, Tönnis) uzun dönemde dejeneratif eklem hastalığı önlenebilir. Bacak maksimum abduksiyonda çekilen kalça radyografisinde femur başının redükte olduğu, örtüldügü ve uyumlu olduğu, ayrıca eklem aralığının korunduğu gösterilmelidir. Eklemde kontraktür olmamalıdır. Bu bulgular periasetabular osteotominin ön şartlarıdır. Bu ameliyat sırasında labral patoloji de tedavi edilir.

Eğer bu grafi ile hastada femur başının sublukse uyumsuz, asferik olduğu görülüyorsa ve dejenerasyon başlamışsa yapılması gereken, muhtemel bir artroplasti ameliyatını geciktirmek amacıyla Chiari mediyal deplasman osteotomisi ya da "shelf" prosedürü olmalıdır. Böylece yük taşıma alanı genişletilerek birim alana düşen stres azaltılmış olur, kalça biyomekaniği iyileştirilir ve dejenerasyonun ilerlemesi önlenmeye çalışılır. ${ }^{[2,33]}$

illeri eklem dejenerasyonu ve eklemde hareket kısıtlılığı geliştiğinde ise tek çare eklem artrodezi ya da artroplasti olabilir.

\section{KOMPLIKASYONLAR}

Enfeksiyon ve diğer erken komplikasyonlar; başarısız redüksiyon, reluksasyon, ekstremite uzunluk farkı, kaynama gecikmesi, kaynamama, pin migrasyonu ve implant yetmezliği, greftle ilgili problemler, eklem sertliği oluşması ve avasküler nekrozdur.

Açık redüksiyon sonrası reluksasyon genellikle hatalı cerrahi tekniğe bağlı gelişir. Bunlar; gerçek asetabulumun yerinin ameliyat sırasında saptanamaması, inferior kapsülün yeterli şekilde serbestleştirilememesi, 
kapsülorafinin kötü yapılması ve femoral ya da pelvik osteotominin hatalı yapılmasıdır. Aşırı derotasyon yapılması, posterior subluksasyon ya da luksasyona yol açabilir. Reluksasyon için yapılan açık redüksiyon ameliyatının sonucunda avasküler nekroz riski artar. ${ }^{[34]}$

GKD tedavisinin en korkulan komplikasyonu, proksimal femurun epifizi ve fizis plağını içeren farklı derecelerdeki büyüme bozukluğudur. Buna aseptik nekroz adı da verilir. Avasküler nekroz, dolaşımın zarar görmesine ya da epifiz kıkırdağının ya da fizis plağının basınç altında ezilmesine bağlı oluşabilir. ${ }^{[13]}$

GKD tanı ve tedavisinde anahtar erken tanıdır. Erken girişim, \%95 başarı oranı ve düşük komplikasyon riski ile sonuçlanır. illk tedavi eden hekimin normal sağlıklı bir kalça elde etme şansı en fazladır. Ortopedik cerrahlar, pediatristleri ve aile hekimlerini erken tanı koymanın önemi ve zamanında doğru yere yönlendirme konusunda eğitmelidir.

\section{KAYNAKLAR}

1. Ponseti IV. Growth and development of the acetabulum in the normal child. Anatomical, histological and roentgenographic studies. J Bone Joint Surg Am 1978;60(5):575-85.

2. Weinstein SL. Developmental hip dysplasia and dislocation. In: Morrissy RT, Weinstein SL, editors. Lovell and Winter's pediatric orthopaedics. Volume 2. 5th ed. Philedelphia: Lippincott Williams and Wilkins; 2001. p.905-56.

3. Wenger DR, Bomar JD. Human hip dysplasia: evolution of current treatment concepts. J Orthop Sci 2003;8(2):264-71.

4. Albinana J, Dolan LA, Spratt KF, Morcuende J, Meyer MD, Weinstein SL. Acetabular dysplasia after treatment for developmental dysplasia of the hip. Implications for secondary procedures. J Bone Joint Surg Br 2004;86(6):876-86.

5. Tümer $Y$, Ağuş $H$, Biçimoğlu $A$. When should secondary procedures be performed in residual hip dysplasia? Acta Orthop Traumatol Turc 2007;41 Suppl 1:60-7.

6. Uzel M, Ergun GU, Ekerbicer HC. The Knowledge and attitudes of the primary care physicians on developmental dysplasia of the hip. Saudi Med J 2007;28(9):1430-4.

7. Yurdoğlu C, Bursalı A, Özgündüz A, Örsel S, Okan E. Unilateral gelişimsel kalça displazilerinde karşı kalça. Acta Orthop Traumatol Turc 1997;31:191-4.

8. Harris NH, Lloyd-Roberts GC, Gallien R. Acetabular development in congenital dislocation of the hip. With special reference to the indications for acetabuloplasty and pelvic or femoral realignment osteotomy. J Bone Joint Surg 1975;57(1):46-52.

9. Wiberg G. Studies on dysplastic acetabula and congenital subluxation of the hip joint. Acta Chir Scand 1939;(83) Suppl 58:7.

10. Morin C, Bisogno J, Kulkarni S, Morel G. Treatment of latepresenting developmental dislocation of the hip by progressive orthopaedic reduction and innominate osteotomy. Our results with more than 30 years of follow up. J Child Orthop 2011;5(4):251-60. CrossRef

11. Ertürk C, Altay MA, Yarimpapuç R, Koruk I, Işikan UE. Onestage treatment of developmental dysplasia of the hip in untreated children from two to five years old. A comperative study. Acta Orthop Belg 2011;77(4):464-71.
12. Shih KS, Wang JH, Wang TM, Huang SC. One-stage correction of neglected developmental dysplasia of the hip by open reduction and pemberton osteotomy. J Formos Med Assoc 2001;100(6):397-402.

13. Kruczynski J. Avascular necrosis of the proximal femur in developmental dislocation of the hip. Incidence, risk factors, sequelae and MR imaging for diagnosis and prognosis. Acta Orthop Scand Suppl 1996;268:1-48.

14. Vallamshetla VRP, Mughal E, O'Hara JN. Congenital dislocation of the hip. A re-appraisal of the upper age limit for treament. J Bone Joint Surg Br 2006;88(8):1076-81.

15. El-Tayeby HM. One-stage hip reconstruction in late neglected developmental dysplasia of the hip presenting in children above 8 years of age. J Child Orthop 2009;3(1):11-20. CrossRef

16. Jager M, Westhoff B, Zilkens C, Weimann-Stahlschmidt $\mathrm{K}$, Krauspe R. Indications and results of corrective pelvic osteotomies in developmental dysplasia of the hip. Orthopade 2008;37(6):556-70, 572-4, 576. CrossRef

17. Wang CW, Wu KW, Wang TM, Huang SC, Kuo KN. Comparison of acetabular anterior coverage after Salter osteotomy and Pemberton acetabuloplasty: a long-term followup. Clin Orthop Relat Res 2014;472(3):1001-9. CrossRef

18. Tukenmez M, Tezeren G. Salter innominate osteotomy for treatment of developmental dysplasia of the hip. J Orthop Surg (Hong Kong) 2007;15(3):286-90.

19. Liu TJ, Shi Y, Pan SN, Liu ZJ, Zhao Q, Zhang LJ, Ji SJ. Evaluaton of mid-term follow-up after Salter innominate osteotomy in developmental dysplasia of the hip. Zhonghua Wai Ke Za Zhi 2010;1;48(15):1149-53.

20. Aydin A, Kalali F, Yildiz V, Ezirmik N, Aydin P, Dostbil A. The results of Pemberton's pericapsular oseteotomy in patients with developmental hip dysplasia. Acta Orthop Traumatol Turc 2012;46(1):35-41.

21. Thielemann F, Schneider A, Köhler T, Dürrschmidt V, Günther KP. Long-term management results of Pemberton's ilium osteotomy in combination with inter-trochanter derotationvarisation osteotomy in hip dysplasia of childhood. Z Orthop Ihre Grenzgeb 2003;141(4):459-64.

22. Papavasiliou VA, Papavasiliou AV. Surgical treatment of developmental dysplasia of the hip in the periadolescent period. J Orthop Sci 2005;10(1):15-21.

23. Umer M, Nawaz H, Kasi PM, Ahmed M, Ali SS. Outcome of triple procedure in older children with developmental dysplasia of the hip (DDH). J Pak Med Assoc 2007;57(12):591-5.

24. Arslan $H$, Kapukaya A, Ibrahim Bekler $H$, Necmioğlu $S$. Is varus osteotomy necessary in one-stage treatment of developmental dislocation of the hip in older children? J Child Orthop 2007;1(5):291-7. CrossRef

25. Sales de Gauzy J. Pelvic reorientation osteotomies and acetabuloplasties in children. Surgical technique. Orthop Traumatol Surg Res 2010;96(7):793-9. CrossRef

26. Gillingham BL, Sanchez AA, Wenger DR. Pelvic osteotomies for the treatment of hip dysplasia in children and young adults. J Am Acad Orthop Surg 1999;7(5):325-37.

27. Carlioz H. Pelvic osteotomies in children and adolescents. Acta Orthop Belg 2000;66(4):321-8.

28. Chang CF, Wang TM, Wang JH, Huang SC, Lu TW. Adolescents after Pemberton's osteotomy for developmental dysplasia of the hip displayed greater joint loading than healthy controls in affected and unaffected limbs during gait. J Orthop Res 2011;29(7):1034-41. CrossRef 
29. Akgül T, Bora Göksan S, Bilgili F, Valiyev N, Hürmeydan OM. Radiological results of modified Dega osteotomy in Tönis grade 3 and 4 developmental dysplasia od the hip. J Pediatr Orthop B 2014;23(4):333-8. CrossRef

30. Bursali A, Tonbul M. How are outcomes affected by combining the Pemberton and Salter osteotomies? Clin Orthop Relat Res 2008;466(4):837-46. CrossRef

31. Kinik $H$, Mergen E. Radical reduction for developmental dislocation of the hip (Cakirgil's procedure). Acta Orthop Traumatol Turc 2007;41 Suppl 1:47-53.
32. Wenger DR. Is there a role for acetabular dysplasia correction in an asymptomatic patient? J Pediatr Orthop 2013;33 Suppl 1:S8-12. CrossRef

33. Kosuge D, Yamada N, Azegami S, Achan P, Ramachandran M. Management of developmental dysplasia of the hip in young adults: current concepts. Bone Joint J 2013;95-B(6):732-7. CrossRef

34. SankarWN, Young CR, Lin AG, Crow SA, Baldwin KD, Moseley $\mathrm{CF}$. Risk factors for failure after open reduction for $\mathrm{DDH}$. a matched cohort analysis. J Pediatr Orthop 2011;31(3):2329. CrossRef 